\title{
The Role of CRime Victims UNDER THE Youth CRIMINAL JUSTICE ACT
}

\author{
KENT ROACH“
}

The author analyzes the role of victim involvement in extrajudicial and judicial measures under the Youth Criminal Justice Act, and the overall direction of victim involvement and its possible impact on the development of youth justice. Unlike the Young Offenders Act, victim concerns are specifically recognized throughout the Youth Criminal Justice Act. With respect 10 judicial measures, reparation should be interpreted broadly to include young offenders' genuine attempts to make good the harms they have caused. The concept of reparation should provide an equal opportunity to pay the costs of crime. With respect to extrajudicial measures. the role of victims is difficull to assess. The author encourages greater utilization of family conferences, as this extrajudicial measure has enjoyed success in New Zealand in reducing youth imprisonment and producing significant levels of victim satisfaction. Victims may well play an increased role under the Youth Criminal Justice Act, but the actual effect of both punitive and non-punitive forms of victim involvement will depend on how the new $A C t$ is administered.
L'auteur analyse le róle de la participation de la victime dans les mesures extrajudiciaires et judiciaires en vertu de la Loi sur le système de justice pénale pour les adolescents et l'impact général de la participation de la victime et l'incidence éventuelle sur le développement de la justice pour les jeunes. Contrairement à la Loi sur les jeunes contrevenants, les inquiétudes des victimes sont reconnues dans la Loi sur le système de justice pénale pour les adolescents. En ce qui concerne les mesures judiciaires, la réparation doit ètre interprétée au sens large et inclure les véritables tentatives des jeunes délinquants à réparer leur faute. La notion de réparation devrait aussi inclure le remboursement des couts relatifs au crime. En ce qui concerne les mesures extrajudiciaires, il est difficile d'évaluer le röle des victimes. L'auseur encourage une plus grande utilisation des conférences de famille. Cette mesure extrajudiciaire connaît un cerlain succès en Nouvelle-Zélande et a permis de réduire la détention des jeunes et d'obtenir des niveaux de satisfaction considerables chez les victimes. Ces dernières pourraient alors jouer un röle plus grand en veru de la Loi sur le système de justice pénale pour les adolescents, mais l'effet réel des formes punitives et non punitives de la participation de la victime dépendra de la manière que la nowvelle loi est administrée.

\section{TABLE OF CONTENTS}

I. INTRODUCTION ...................... 966

II. THEMES CONCERNING VICTIM INVOLVEMENT IN

Youth CRIMINAL Justice . . . . . . . . . . . . . . . . . . . . . 967

A. PUNITIVE AND NON-PUNITIVE FORMS OF

VICTIM INVOLVEMENT . . . . . . . . . . . . . . . . . . . 967

B. GENERAL AND YOUTH-SPECIFIC VICTIM CONCERNS ...... 969

C. THE Preamble of the Youth CRIMINal JUSTICE ACT . . . 970

D. THE PRINCIPLES OF THE YOUTH CRIMINAL JUSTICE ACT . . . 972

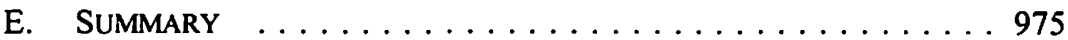

III. EXtrajudicial MEASURES $\ldots \ldots \ldots \ldots \ldots \ldots \ldots \ldots$

Professor of Law, University of Toronto. A much earlier version of this article was originally prepared for the federal Department of Justice. I thank all the officials involved, while adding that this article represents only my own views. 

A. SECTIONS 5(B) AND (D) OF THE

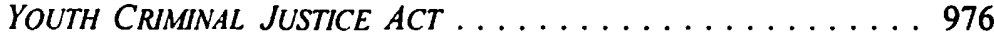

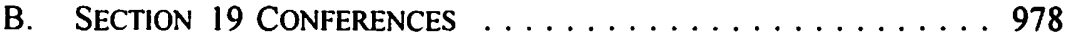
C. FAMILY CONFERENCES ................. 978
D. THE IMPORTANCE OF FEDERAL SPENDING POWER . . . . . 980

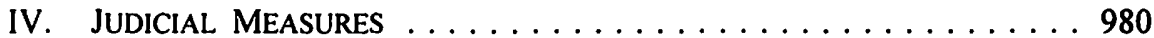

A. Victims and the TRIAl Process $\ldots \ldots \ldots \ldots \ldots \ldots . \ldots 91$

B. Victims and PUblication Bans ............981

C. A NEW EMPHASIS ON REPARATION IN SENTENCING . . . . . 982

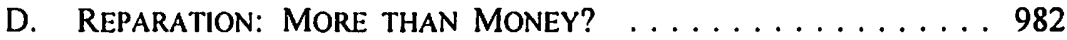

E. REPARATION AND THE CIRCUMSTANCES OF ABORIGINAL OFFENDERS $\ldots \ldots \ldots \ldots \ldots \ldots \ldots \ldots$

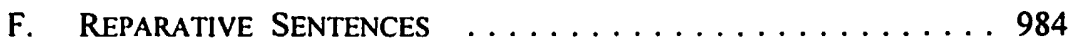

G. FINES AND FINE SURCHARGES $\ldots \ldots \ldots \ldots \ldots \ldots \ldots \ldots 95$

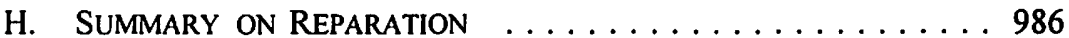

I. VICTIM IMPACT STATEMENTS $\ldots \ldots \ldots \ldots \ldots \ldots \ldots 96$

V. ConClusions $\ldots \ldots \ldots \ldots \ldots \ldots \ldots \ldots \ldots \ldots$

\section{INTRODUCTION}

It should not be surprising that the new Youth Criminal Justice Act ${ }^{1}$ provides a much greater role for victims of youth crime than the Young Offenders Act. ${ }^{2}$ The YOA was developed in the early 1980s alongside the Canadian Charter of Rights and Freedoms, ${ }^{3}$ at a time when the emphasis in criminal justice was on the accused and the state. The YOA's themes of rights and responsibilities reflected this bipolar focus. As with the Charter, there was no explicit mention of crime victims in the YOA as first introduced. In contrast, the $Y C J A$ was developed in the late 1990s when an increasing emphasis was placed on victims in criminal justice. It would be strange indeed if the YCJA did not mention crime victims.

However, new concerns about victims in criminal justice policy do not point in one direction. Increased interest in crime prevention, and especially restorative justice, represents a non-punitive direction for victim involvement in the criminal justice system. In the 1990s, a global movement towards restorative justice gathered momentum and made a special impact on youth justice, especially in New Zealand. The focus of restorative justice is on diversion from prosecutions within the court system. This permits disputes arising from crime to be resolved with community (including victim) participation, and without relying on punishment following a criminal trial or a guilty plea. The $Y C J A$ reflects this trend by allowing conferences to be convened at various stages of youth criminal justice proceedings and by contemplating communitybased programs, such as victim-offender reconciliation, mediation and restitution programs.

S.C. 2002, c. 1 [hereinafter $Y C J A$ ].

R.S.C. 1985, c. Y-1 [hereinafter YOA].

Part I of the Constitution Act, 1982, being Schedule B to the Canada Act 1982 (U.K.), 1982, c. 11 [hereinafter Charter]. 
But there is also a punitive direction for increased victim involvement in the criminal justice system. One manifestation of increased victim interest in punishment is the introduction of victim impact statements (these were added to the YOA in the 1995 amendments and will continue under the $Y C J A$ ). Another manifestation is an increased emphasis on reparation and acknowledgement of harm to victims and the community as purposes of sentencing. Victims' bills of rights in various jurisdictions have asserted that crime victims have the right to information as their cases progress through the criminal justice system, and the right to be treated with courtesy and respect during all stages of the criminal prosecution. In some cases, the rights of crime victims are asserted as a reason for limiting the rights of the accused, or at least as a new factor to throw into the balance. The $Y C J A$ reflects the trend towards increased concern about victims in the prosecution and punishment of crime.

The first part of this article introduces the analytical and critical themes used to classify and evaluate the various victim initiatives in the $Y C J A$ and the various practices that may be implemented under it. I also discuss the principles of the $Y C J A$ to illustrate how they relate to the broad themes introduced in this section. The second part of the article focuses on the possible role of victims in extrajudicial measures, and will examine some of the secondary literature on restorative justice, with particular emphasis on the role of victims. The third part examines the role of victims in judicial measures, with particular attention to reparation as a new purpose of sentencing and the role of victim impact statements. Again, reference will be made to secondary literature, although this literature is much less robust and has so far not focused on youth (as opposed to adult) justice. Finally, conclusions about the overall direction of victim involvement and its possible impact on the development of youth justice under the $Y C J A$ are briefly assessed.

\section{Themes Concerning Victim Involvement in Youth CRiminal Justice}

Criminal justice in Canada, and elsewhere, has been reoriented significantly in the last decade. It is no longer accurate to describe Packer's famous crime control and due process models as the only normative or positive guides to criminal justice. ${ }^{4}$ Society remains interested in crime control and the accused's due process rights. The last decade has, however, seen an increased recognition of the concerns of victims, and potential victims, of crime. These new concerns about victims can point in different directions.

\section{A. Punitive and Non-Punitive Forms of Victim Involvement}

The dominant direction, particularly at the level of legislative reform, has been towards a punitive model of victims' rights, with a focus on the criminal trial process and the imposition of punishment. The goal in this approach is to facilitate the

H.L. Packer. The Limits of the Criminal Sanction (Stanford: Stanford University Press. 1968); H.L. Packer, "Two Models of the Criminal Process" (1964) 113 U. Pa. L. Rev. 1. For an early argument that Packer's models did not exhaust the values of criminal justice, especially those represented by child welfare-based systems of juvenile justice, see J. Griffiths, "Ideology in Criminal Procedure or a Third 'Model' of the Criminal Process" (1970) 79 Yale L.J. 359. 
application of criminal sanctions, and to do so in a manner that is less harmful to victims. Thus the privacy, dignity and equality interests of victims are recognized and protected from some abusive forms of cross-examination. ${ }^{5}$ Reparation and acknowledgement of harm have been recognized as new goals of sentencing. ${ }^{6}$ Although these new goals are not usually associated with the use of imprisonment, they remain punitive in the sense that they come into play after an offender has been found guilty as the result of a formal criminal prosecution. Victims are perceived as consumers of criminal justice, and they have the right, generally under provincial victims' legislation, to be informed about the progress of their case through the criminal trial process. A special emphasis is placed on victim impact statements, which are, of course, tied to the punishment that the offender receives.

The alternative direction that has influenced local practice, ${ }^{7}$ and some forms of legislative reform in Canada and abroad, is towards a non-punitive model of victims' rights, with a focus on crime prevention and restorative justice. Often, the goal in this approach is to protect the interests of victims and potential crime victims by preventing crime and providing reparation and acknowledgement of the harm done to victims and the community. This non-punitive model of victims' rights is often associated with restorative justice. In sentencing cases that involve the imposition of imprisonment and conditional sentences, ${ }^{8}$ the Supreme Court of Canada has recognized that restorative justice can be connected with concerns about the offender's rehabilitation and restraint in the use of imprisonment. ${ }^{9}$ Also, within some forms of restorative and Aboriginal justice, there is a recognition that the category of who is a victim is fluid and that an offender's behaviour may be related to his or her past victimization. ${ }^{10}$ This is particularly important in youth justice where there has been a disconnect in the last two decades between our recognition that children are often the victims of abuse and violence, and our concern about getting tough on crime committed by teenagers. In a non-punitive model of victims' rights, special emphasis is placed on diversion, which facilitates restorative justice.

R. v. Mills, [1999] 3 S.C.R. 668.

Criminal Code, R.S.C. 1985, c. C-46, ss. 718(e) and (f) [hereinafter Criminal Code] as interpreted in R. v. Gladue, [1999] I S.C.R. 688 [hereinafter Gladue] and R. v. Proulx, [2000] I S.C.R. 61 [hereinafter Proulx].

7 See Church Council on Justice and Corrections, Satisfying Justice (Ottawa: Correctional Service of Canada, 1996) for a compendium of restorative justice projects operated at the local level throughout Canada.

* Supra note 6.

"The fact that cases such as Gladue and Proulx, ibid, can be classified under both punitive and non-punitive models of victims' rights reflects the ambiguity of discourse about restorative justice. For some, restorative justice is primarily about diversion from the existing criminal justice system, while for others the focus is on providing accountability and reparation either within or outside the existing criminal justice system. On the various guises of restorative justice see $\mathrm{K}$. Roach, "Changing Punishment at the Turn of the Century: Restorative Justice on the Rise" (2000) 42 Can. J. Crim. 249.

1" R. Ross, Returning to the Teachings: Exploring Aboriginal Justice (Toronto: Penguin, 1996); P.A. Monture-Okanee \& M.E. Turpel, "Aboriginal Peoples and Canadian Criminal Law: Rethinking Justice" (1992) U.B.C. L. Rev. 239; J. Rudin, "Alternative Sentencing" in P. Healy \& H. Dumont, eds., Dawn or Dusk in Sentencing (Montreal: Thémis, 1997). 
The concepts of punitive and non-punitive approaches to victim involvement that 1 have developed in other work ${ }^{\prime \prime}$ are used in this article to classify and assess victim involvement under the $Y C J A$. Punitive concerns are categorized very roughly under judicial measures, while non-punitive concerns are categorized under extrajudicial measures. However, there are some overlaps, with reparative sanctions under judicial measures following a less punitive approach and some failed attempts to undertake extrajudicial measures resulting in a punitive response. In addition, the very concept of restorative justice is somewhat ambiguous and can be interpreted to include both punitive and non-punitive measures. ${ }^{12}$

\section{B. General AND Youth-SPECIFIC. Victim CONCERNS}

Another important conceptual distinction used in this article is that between victim concerns that are generic to all forms of criminal justice, and those that are specific to youth justice. The YCJA especially (as compared to its predecessors) contemplates a significant role for crime victims, both in extrajudicial measures and at sentencing. This reflects broad trends in Canadian criminal justice policy that have seen the provinces enact various victims' bills of rights and Parliament enact legislation designed to respond to the concerns of crime victims and potential crime victims (especially women and children). In this way, many victims' concerns in the $Y C J A$ cut across criminal justice, and are not particular to youth criminal justice. For example, all crime victims, regardless of whether the crime was committed by an adult or a young person, arguably should have the right to be treated with respect and to be informed about the proceedings. Many of the victim initiatives contained in the YCJA reflect these generic concerns. Generic victim concerns may play a role in bringing youth justice closer to adult justice. To the extent that they embrace a punitive model of victims' rights, generic victim concerns may also make youth justice more punitive.

At the same time, there are victim concerns that are particular to youth justice. The tailoring of victim concerns to youth criminal justice cuts in two directions. In some cases, because of the special nature of youth justice and its primary emphasis on rehabilitation and preventing youth crime, it may be inappropriate to give victims the full range of rights or entitlements that they would have in the adult system. Although this position is not accepted in the $Y C J A$, it is arguable that victim impact statements should be restricted in youth justice proceedings because they may lead to excessive emphasis on punishing crime, as opposed to rehabilitation. Similarly, because of concerns about rehabilitation, victims may not be entitled to the same amount of information about young offenders as about adult offenders. Concern about preserving a distinct approach to youth justice may limit the degree to which victim concerns, especially punitive victim concerns, are integrated into youth criminal justice.

" K. Roach, Due Process and Victims' Rights: The New Law and Politics of Criminal Justice (Toronto: University of Toronto Press, 1999) [hereinafter Due Process]; K. Roach, "Four Models of the Criminal Process" (1999) 89 J. Crim. L. \& Criminology 671. 
However, youth-justice-specific concerns may cut in the other direction. There may be valid reasons for more, not less, victim involvement in youth justice than in adult justice. Victim involvement in youth justice, especially non-punitive forms of involvement, may play an important role in making youths realize the consequences of their crimes, and may assist in holding them accountable for crime in a manner that facilitates their reintegration with society (including the victim). In New Zealand and elsewhere, policy-makers have recognized that restorative justice is particularly important in youth justice. Family conferences that bring young offenders and their supporters together with victims and their supporters may be particularly important in youth justice. The age of the offender may indicate that he or she has more to learn from such conferences, while some victims may be more forgiving and more concerned with the offender's rehabilitation and reintegration when the offender is young. There may also be a more direct connection between a young person's experience as the victim of crime or parental neglect and his or her offending behaviour than is the case with adult offenders. Further, family conferences may also be amenable to child welfare proceedings, which in New Zealand are also conducted using the family conference model.

With respect to non-punitive interventions, there is a persuasive argument that victim involvement should be greater in youth, as opposed to adult, justice. With respect to punitive interventions, the case is less clear. Arguably, in order to preserve the special place of rehabilitation and reintegration in youth justice, there should be less victim involvement in youth justice. In what follows, the preamble and statement of principles in the $Y C J A$ are assessed to determine the degree to which they reflect punitive and non-punitive victim concerns, and the degree to which these victim concerns are specific to youth justice or generic to all forms of criminal justice.

\section{The Preamble of the Youth Criminal Justice act}

Preambles are increasingly incorporated into federal criminal justice legislation and have been used in the adult criminal justice system to signal concerns for crime victims. ${ }^{13}$ For example, concerns about women and children who are the victims and potential victims of violence have figured prominently in the preambles of parliamentary replies to Supreme Court of Canada decisions perceived in Parliament as placing too much emphasis on the rights of the accused in sexual assault cases. Generally, preambles have not played an important role in the interpretation of legislation, but the Supreme Court of Canada did take note in $R$. v. Mills ${ }^{14}$ of the preamble in the parliamentary reply to its controversial decision in $R$. v. $O^{\prime}$ Connor. ${ }^{15}$ Preambles have been used in other bills, including the 1999 Criminal Code amendments concerning crime victims. ${ }^{16}$ At their best, preambles represent a genuine attempt to set

See K. Roach, "The Uses and Audiences of Preambles in Legislation" (2001) 47 McGill L.J. 129. [1999] 3 S.C.R. 668 at para. 48.

[1995] 4 S.C.R. 411; An Act to amend the Criminal Code (production of records in sexual offence proceedings), S.C. 1997, c. 30.

An Act to amend the Criminal Code (victims of crime), S.C. 1999, c. 25. 
out the purposes and aspirations of legislation. At their worst, they represent a symbolic, but otherwise meaningless, gesture to political concerns.

Although victims are not mentioned in the preambles of earlier versions of the $Y C J A,{ }^{17}$ they are now included in the following paragraph of the $Y C J A$ 's preamble:

And Whereas Canadian society should have a youth criminal justice system that commands respect, takes into account the interests of victims, fosters responsibility and ensures accountability through meaningful consequences and effective rehabilitation and reintegration, and that reserves its most serious intervention for the most serious crimes and reduces the over-reliance on incarceration for nonviolent young persons.

Support for both punitive and non-punitive approaches to victim concerns can be found in this paragraph.

On the one hand, the reference to the need for the youth criminal justice system to command respect, in part by taking into account the interests of victims, seems to acknowledge the legitimacy of the criticism that the $Y O A$ was not tough enough on youth crime. Critics of the YOA argued that it allowed young people to escape responsibility and accountability for crime, and that it brought the administration of youth justice into disrepute because it did not hand out tough enough sentences. Victim concerns played an important role in this critique of the $Y O A$. One concern was that the three-year maximum punishment for even serious personal injury offences under the $Y O A$ did not adequately acknowledge the lifelong injuries sustained by victims of youth crime or the suffering of those that lost family members to youth crime. The reference in the $Y C J A$ to needing to take into account the "interests of victims" can be interpreted as referring to an assumed interest of victims in tougher sentences, including the "adult sentences" that are available under the YCJA. The "interests of victims" can also be interpreted as an interest not only in punishment, but also in information about how a case will be prosecuted in the vouth criminal justice system. ${ }^{18}$ The above victim interests are generic to all forms of criminal justice, and largely tied to punishment.

However, the preamble can also be interpreted in a manner that supports a less punitive approach to youth crime. The idea implicit in the above quotation that the interests of victims are linked with "responsibility," "accountability" and "meaningful consequences" can include restorative justice. One of the stronger arguments in favour of restorative justice is that it allows offenders to accept responsibility for the wrongs they have committed. Facing those affected by the offence, including victims, can censure the offender in a way that is more meaningful and more intense than courtroom proceedings, where the offender and the victim are not allowed to speak with each

See, e.g., Bill C-68, An Act in respect of criminal justice for young persons and to amend and repeal other Acts, Ist Sess., 36th Parl., 1997 (1st reading 11 March 1999); and Bill C-3, An Act in respect of criminal justice for young persons and to amend and repeal other Acts, 2d Sess.. 36th Parl., 1999 (2d reading 23 November 1999). justice, youth crime and the effectiveness of measures taken to address youth crime should be publicly available." 
other and the offender's participation is often indirect and inconsequential. ${ }^{19}$ It should not be assumed that restorative justice is not a vehicle for accountability, consequences and censure of offenders. The reference in the above quotation to "effective rehabilitation and reintegration" and the goal of reducing the "over-reliance on incarceration for non-violent young persons" also supports the idea that the "interests of victims" may include dispositions that keep the young offender out of jail — but allow the offender to make restitution or reparation for the property damage that the victims of many youth crimes suffer.

Other parts of the preamble recognize that "members of society share a responsibility to address the developmental challenges and the needs of young persons and to guide them into adulthood," and that "communities, families, parents and others concerned with the development of young persons" have a role in preventing youth crime and responding to the needs of young persons. It is perhaps significant that the preamble does not specifically recognize the role that crime victims can play in this respect. Through participation in diversion programs or victim impact statements, crime victims can help offenders realize the consequences of their (perhaps impulsive) crimes. The failure to mention this potential role of crime victims is perhaps explained by the principle in s. 3(d)(ii) of the $Y C J A$ that victims "should suffer the minimum degree of inconvenience as a result of their involvement with the youth criminal justice system." Crime victims are involuntarily chosen to be crime victims, and they should not be involuntarily conscripted and perhaps re-victimized by being forced to participate in youth criminal justice proceedings. Nevertheless, crime victims can play a valuable role in the offender's acceptance of responsibility, should victims freely decide to do so.

\section{The Principles of the Youth CRIMINal Justice aCt}

As part of the operative text, the principles of the $Y C J A$ are likely to play a more important role in the interpretation of the new legislation than is the preamble. It is thus significant that the $Y C J A$, unlike the $Y O A$, mentions crime victims in its principles. This is an important addition, and affirms that crime victims have assumed a significant role in youth justice. The manner in which victims are included in the principles should be closely examined because it may establish broad policy orientations that will influence victim involvement in later parts of the YCJA.

Section 3(1)(c)(ii) provides that, within the limits of fair and proportionate accountability, the measures taken against young persons should "encourage the repair of harm done to victims and the community." This presumably refers to both extrajudicial measures and judicial measures, including sentences that require reparation. This parallels the new emphasis placed on reparation to victims and the community in the adult system. ${ }^{20}$

19 Roach, supra note 9 at 263-65; J. Roberts \& K. Roach, "From Circles to Sentencing: Restorative Justice in Canada" in A. von Hirsch et al., eds., Restorative Justice and Criminal Justice: Competing or Reconciliable Paradigms (Oxford: Hart Publishing, 2003) 237.

: Criminal Code, supra note 6, ss. 718(e) and (f). 
There is ambiguity in the principles, as reparation to the community can blur towards more traditional forms of punishment (such as fines and imprisonment), while reparation to the victim usually involves more innovative sanctions that do not engage the use of imprisonment. Little new will be added to our approach to youth crime if punishment by the state is simply termed repair of harm done to the community. There is also ambiguity in the concept of "the community." Youth crime may affect particular communities: other young people are frequently the victims of youth crime and crime may have a disproportionate impact on disadvantaged communities. However, in cases of shoplifting, the relevant community may be the small or large merchant. Even though many different communities are affected by youth crime, the $Y C J A$ simplifies and romanticizes these communities by referring to them as "the community."

Even if greater emphasis is placed on repair of harm done to the victim, as opposed to "the community," some problems remain. One is the relevance of unintended and unforeseen harm done to the victim. The sentencing principles of the $Y C J A$ direct the judge's attention to "the harm done to victims and whether it was intentional or reasonably foreseeable." ${ }^{21}$ In contrast, its principles refer only to the repair of the harm suffered. From the victim's perspective, it makes little difference whether the harm suffered was intended or even reasonably foreseeable; the victim has suffered harm and will want some form of reparation.

Nevertheless, it may be unfair to hold the offender accountable for unforeseen harm. Even where a reasonable person would have foreseen the harm, it is relevant to the culpability of young offenders if they did not intend or subjectively advert to the harm. In recent years, the criminal law as applied to adults has placed more emphasis on the harm caused by the offender, as opposed to whether the offender was subjectively at fault for causing that harm. Irrespective of the desirability of this development with respect to adult offenders, it may simply not be appropriate for young offenders. The innocent intention of some young offenders may be particularly relevant to a proper disposition. It is thus important that the reference to encouraging the repair of harm caused to victims in s. 3(c) of the $Y C J A$ is placed "within the limits of fair and proportionate accountability." The principles of proportionality suggest that offenders are most responsible when they have subjectively adverted to the harm that they caused. $^{22}$ In addition, s. $38(3)(\mathrm{b})$ of the $Y C J A$ suggests that in some cases young offenders may be required to repair reasonably foreseeable harms caused to the victim. However, they should not be required to repair harm that was neither subjectively nor reasonably foreseen.

Another potential problem in interpreting the principle of repair of harm caused to victims in s. $3(1)(c)(i i)$ is the danger of it being limited to monetary restitution. As discussed below, young offenders from economically disadvantaged backgrounds may not be able to make monetary restitution. However, the idea of repair is arguably richer than restitution and may include the acknowledgement of harm, acceptance of responsibility and apologies. Nicholas Bala suggests that this principle reflects a 
restorative justice approach in which "Some form of reparation of harm, whether by means of an apology, performance of services or compensation to a victim, tends to make the consequences of offending more meaningful to the youth" and can help "restore harmonious relationships between the offender and those who have been harmed by the offence, namely the victim and the community." 23 This broader interpretation of repair recognizes that in a society of radically unequal distribution of wealth, there is a danger of reducing restorative justice to restitution.

Sections 3(d)(ii) and (iii) also make special reference to victims of crime: in particular, the need to treat them with courtesy, compassion and respect for their dignity and privacy, and to provide them with information about the proceedings and an opportunity to participate and be heard in the proceedings. Although s. 3(d) states that the above are "special considerations" that "apply in respect of proceedings against young persons," the above considerations are really generic victim concerns that apply not only to youth justice, but to adult justice. Thus, as discussed in the third part of this article, it appears that victims will have the same right to make oral victim impact statements in youth proceedings as they have in adult proceedings. The principles articulated in s. 3(d)(ii) and (iii) are found in most provincial victims' legislation where they have generally been found by courts not to be enforceable.

Some commentators have criticized s. 3(d)(ii) and (iii). Sanjeev Anand argues that to the extent that they suggest that prosecutors and other criminal justice officials must inform victims, even where they have not expressed an interest in the matter, they should be repealed or amended. He fears that the obligation to inform victims of numerous court appearances may divert resources from crime prevention and diversion programs, and cause prosecutors to become more punitive. ${ }^{24}$ The concern about diverting resources from offenders to victims may be legitimate in cases where not enough resources are devoted to youth criminal justice. It is also possible that requiring prosecutors to consult victims may in some cases make them more punitive. Nevertheless, similar obligations may already be placed on prosecutors by provincial legislation. ${ }^{25}$ Moreover, prosecutors have an obligation to form an independent view of what disposition is in the public interest. If victims are to be informed about proceedings, the provinces must be in a position to provide services to victims and to structure proceedings so as to make victim involvement meaningful.

My own concern is more with the statement in s. 3(d)(ii) that victims "should suffer the minimum degree of inconvenience as a result of their involvement with the youth criminal justice system." Extrajudicial measures (such as family conferences) that involve the victim will likely cause victims more inconvenience than other forms of diversion or cautioning, or even judicial measures. Victim involvement in extrajudicial measures is voluntary. One of the major obstacles to this type of involvement is convincing victims that they should spend time attending a family conference or victim- 
offender reconciliation program. The promise of a minimum degree of inconvenience sends out an inappropriate message with respect to extrajudicial measures. With respect to judicial measures, it may also sound something of a false promise. As witnesses, victims are compelled to testify. They can be subject to cross-examination on their victim impact statements. The accused has the right to retain counsel and to prepare a defence - even if this causes delay and inconvenience for the victim. The minimum degree of inconvenience principle seems to conceive of victims as the consumers of criminal justice. However, we should never forget that crime victims are involuntary, and often unhappy, consumers. The trial process is not designed, and can never be designed, to maximize victim satisfaction or convenience.

\section{E. SUMMARY}

The YOA was introduced in the 1980s under the conceptual banner of the rights and responsibilities of young offenders, and at a time when criminal justice was seen as a matter between the accused and the state. The YOA represented a conscious change from the family and paternalistic orientation of the Juvenile Delinquents Act. ${ }^{26}$ The $Y C J A$ builds on the theme of rights and responsibilities, but introduces victim concerns as another major, but perhaps slightly subordinate, theme. Some victim concerns reflected in the YCJA focus on prosecution and punishment. Others focus on diversion, reparation and restorative justice.

\section{Extrajudiclal Measures}

Sections 4 through 12 and 157 of the $Y C J A$ govern extrajudicial measures. There is a recognition that such measures "are often the most appropriate and effective way to address youth crime" and a presumption that such measures are "adequate to hold a young person accountable for his or her offending behaviour if the young person has committed a non-violent offence and has not previously been found guilty of an offence."27 Extrajudicial measures are not precluded in other cases, but the focus on reparation suggests that property crime is the paradigm for extrajudicial measures.

The $Y C J A$ contemplates a greater role than the $Y O A$ for crime victims to participate and benefit from extrajudicial measures. In general, the $Y C J A$ contemplates that crime victims can be informed about extrajudicial measures and may participate in them, and that they should receive reparation and acknowledgement of the harm they suffered. However, at the same time, the $Y C J A$ does not go as far as New Zealand legislation in endorsing a restorative justice and conference-based approach to youth crime ${ }^{28}$ This is unfortunate because there is evidence that Canada diverts young offenders much less often than do New Zealand, England and even the United States, and that this results

26. R.C. 1970 , c. J-3.

$27 \quad$ YCJA, supra note I, s. 4(a) and (c).

28 New Zealand's Children. Young Persons and their Families Act 1989, S.N.Z. No. 24. s. 208 [hereinafter Children. Young Persons and their Families Act] provides that "unless the public interest requires otherwise, criminal proceedings should not be instituted against a child or young person if there is an alternative means of dealing with the matter." See Due Process, supra note 11 at 215-19. 
in Canada making much greater use of custodial sentences than all those countries. ${ }^{29}$ Although the $Y C J A$ is flexible enough to allow diversion and conferencing to flourish at the local level, it does not provide strong incentives, leadership or guidance for the measures that are urgently required to reduce Canada's high reliance on the imprisonment of young offenders.

The $Y C J A$ introduces the new concept of police and Crown cautions as extrajudicial measures of first resort. Extrajudicial sanctions administered in a diversion program under s. 10 only come into play if a police or Crown caution is not adequate "because of the seriousness of the offence, the nature and number of previous offences committed by the young person or any other aggravating circumstances." The United Kingdom has much more experience with police cautions and there have been some interesting recent experiments in that country that attempt to use police cautions in a manner that draws on restorative justice. Restorative cautions are administered in the presence of family or other supporters of the offenders and, where possible, in the presence of crime victims and their supporters. However, the available research suggests substantial difficulties in having the cautions administered by the police in a truly restorative manner. ${ }^{30}$ This raises the more general question of whether restorative justice will be corrupted and made more punitive as it is integrated into mainstream criminal justice processing.

\section{A. Sections 5(B) AND (D) OF THE Youth CRIMINal JUSTICE ACT}

Unlike s. 4(b) of the $Y O A$, which refers to alternative measures responding to the needs and interests of young persons and society but not to victims, s. 5 of the $Y C J A$ mandates that extrajudicial measures should respond to the needs of crime victims. Section 5 provides that "extrajudicial measures should be designed to ... (b) encourage young persons to acknowledge and repair the harm caused to the victim and the community; ... [and] (d) provide an opportunity for victims to participate in decisions related to the measures selected and to receive reparation." Victim-offender reconciliation programs, mediation and restitution programs (all specifically mentioned in s. 157 as community-based programs that may be approved as an alternative to judicial proceedings) are particularly well-suited to allowing the harm caused to victims to be acknowledged and repaired. However, it should be noted that these provisions do not give victims a clear right to participate in extrajudicial measures, but only the "opportunity for victims to participate in decisions related to the measures selected and to receive reparation" and the right under s. 12 of the YCJA to be informed on request and after the fact about the disposition of the offence. In contrast, the 1994 amendments to New Zealand's Children, Young Persons and their Families Act $t^{31}$ gave victims and their supporters a right to attend family conferences. It may be frustrating for victims

Bala, supra note 23 at 135 .

R. Young \& B. Goold, "Restorative Police Cautioning in Aylesbury - From Degrading to Reintegrative Shaming Ceremonies?" [1999] Crim. L.R. 126; R. Young \& C. Hoyle. "New, Improved Police-Led Restorative Justice: Action Research and the Thames Valley Police Initiative" in von Hirsch et al., supra note 19 at 273.

$3 \quad$ Children. Young Person's and Their Families Amendment Act, S.N.Z. 1994, No. 121, s. 37. 
to have rights to be consulted about which extrajudicial measure will be used and to be informed of the result, but no right to participate in the extrajudicial measure.

When read in conjunction with the presumption in s. 4(c) that extrajudicial measures are adequate for non-violent offences, ss. 5(b) and (d) may be thought to refer mainly to repair of and reparation for property crime - the type of crime that forms the bulk of charges in youth court. This raises the issue of whether all young offenders will be in a position to make monetary payments, and the possibility of class bias if reparation is limited to monetary compensation. Repair of harm should be conceived of broadly: sometimes a sincere apology goes a long way to repair harm.

Monetary payments and other forms of reparation may have a role to play in response to non-property crimes. Although it still found that imprisonment was required, the Supreme Court of Canada noted in $R$. v. R.A.R. ${ }^{32}$ that a $\$ 10,000$ payment by an employer convicted of assaulting and sexually assaulting an employee fulfilled restorative principles under s.718(e) of the Criminal Code. However, reliance on such payments raises distributional or class issues. A focus on monetary reparation may also raise false hopes in victims, leaving them dissatisfied when such monetary compensation is not available from young offenders who do not have access to significant monetary sums. ${ }^{33}$

Section 5(d) contemplates that victims will have an opportunity to participate in decisions related to the extrajudicial measures selected. This will require prosecutors or victim offices to contact victims at an early stage about possible diversion options. One potential reaction of victims is to resist extrajudicial measures as not taking the crime seriously. The officials that contact victims must have the time and experience necessary to answer any questions that crime victims have about whether various extrajudicial measures are meaningful and appropriate. Under s. 12 of the $A c t$, victims may request information concerning the identity of the offender and the disposition of the offence. This provides an opportunity to study victim satisfaction with different forms of extrajudicial measures. For example, will victims be less satisfied with policeadministered cautions than with measures that involve the victims themselves? Section 12 will not in itself produce a random sample because it only applies to victims who specifically request information. Nevertheless, studies of victim satisfaction in relation to various forms of extrajudicial measures should be a priority.

Victims who are very dissatisfied with extrajudicial measures retain a right under s. 10(6) to initiate a private prosecution. This right, if exercised, marks a move from a non-punitive to a punitive response. However, the right of a private prosecution is something of a false promise to victims. Section 24 of the $Y C J A$ states that the Attorney General must consent to such a prosecution. A young person may also receive protection from prosecution under s. $10(5)$ if he or she has complied, or even partially

[2000] I S.C.R. 163.

See T. Dittenhoffer \& R. Ericson, "The Victim/Offender Reconciliation Program: A Message to Correctional Reformers" (1983) 33 U.T.L.J. 315 for an account of a program that held out monetary reparation as a reason to involve victims. many of whom were corporations. 
complied, with the extrajudicial measure. One of the weaknesses of punitive measures that rely on prosecutions is that victims have limited participatory rights. Although such participatory rights are not explicitly guaranteed under s. 5(d), crime victims may have more robust participatory rights in extrajudicial, as opposed to judicial, measures.

\section{B. SECTION 19 CONFERENCES}

Section 19 of the $Y C J A$ empowers judges, provincial directors, police officers or any other person to convene a conference for the purpose of making a decision under the $Y C J A$. The mandate of the conference may be to give advice on appropriate extrajudicial measures or other decisions under the $Y C J A$, including release from custody, sentences and "reintegration plans." Youth justice committees may also act as a conference. ${ }^{34}$ Youth justice committees may, under s. 18(2)(a)(ii), facilitate the reconciliation of the victim and the young person, suggesting that a s. 19 conference might take the form of a victim-offender reconciliation program as contemplated under s. 157 of the YCJA.

The use of s. 19 conferences is difficult to predict. The $Y C J A$ empowers a wide range of persons to convene a conference, but provides no structure with respect to the procedures or the aims of the conference. Some s. 19 conferences could be genuine family conferences or victim-offender reconciliation programs, but they could also be consultations between criminal justice professionals about whether a young offender will be released on bail or about the duration of his or her sentence. The frequency of s. 19 conferences and their objectives will depend on local practice and provincial directives. A particular province may establish rules for convening and conducting conferences that apply to all officials (except judges). This provides an opportunity for provinces to limit or encourage conferences, and to provide some structure and theory (such as restorative justice) to guide the participants.

\section{Family CONFerences}

Section 19 could be used to convene family conferences. Family conferences are restorative interventions designed to bring together the offender and his or her supporters, the victim and his or her supporters, and others who have been affected by the offence. Unlike in New Zealand, there is no specific requirement for family conferences under the $Y C J A$, and s. 19 does not suggest a structure where family conferences are convened. Section 19 does not even mention family conferences even though the phrase appeared frequently in public discussions of various versions of the bill. As suggested below, the reluctance to encourage, structure or even mention family conferences in the $Y C J A$ is unfortunate given the generally positive evaluations of family conferences, including evaluations measuring victim satisfaction.

If a s. 19 conference is convened by a youth justice committee, s. 18(2)(ii) suggests that the youth justice committee should support the victim "by soliciting his or her concerns and facilitating the reconciliation of the victim and the young person." Support 
for the victim is important, but the theories of reintegrative shaming and restorative justice that underlie family conferences suggest that offenders, as well as victims, should receive support. If only the victim receives support, there is a danger that young offenders will be stigmatized and offer up defiance and resistance to shame. ${ }^{35}$ Although s. 19 conferences are meant to be informal, there should be some procedural guidelines to ensure that both victims and offenders participate on a voluntary basis and are given an opportunity to tell their side of the story. ${ }^{36}$ Section $10(2)(c)$ requires that young offenders fully and freely consent to extrajudicial sanctions, but there is no explicit requirement that the young person or the victim consent when a conference is convened under s. 19. The consent of both the accused and the victim should generally be obtained before a family conference. Requiring consent should ensure that no one is coerced into participation and provides a good start for the conference proceedings.

Unlike in New Zealand, the YCJA has no specific requirement for family conferences, leaving actual use and procedures to local practice. The failure to encourage and structure family conferences is unfortunate because the available research suggests that they can be quite effective, not only in reducing reliance on the incarceration of young offenders, but also in securing significant levels of victim satisfaction. Based on their observational studies of family conferences, Braithwaite and Mugford conclude that victim participation is crucial to the success of family conferences both in shaming offenders and offering them a means of reintegration. They claim that family conferences "can deliver victim satisfaction that the courts can never deliver." ${ }^{37}$ However, most studies show that, while there are high rates of victim satisfaction with family conferences, victims are somewhat less satisfied than other participants. A New Zealand study found that 60 percent of victims who attended family conferences were satisfied, as opposed to 80 percent of offenders. ${ }^{38}$ There was 89 percent victim satisfaction at four Canadian sites for victim-offender mediation. In one Australian study, while 60 percent of victims felt "quite" or "very" angry before family conferences, only 30 percent felt so afterwards. ${ }^{39}$ There are no guarantees.

See J. Braithwaite, Crime, Shame, and Reintegration (Cambridge: Cambridge University Press, 1989); J. Braithwaite, "Shame and Criminal Justice" (2000) 42 Can. J. Crim. 28I. Note, however. some theorists argue that shame without a focus on reintegration and reconciliation can serve as an effective alternative to imprisonment that serves the societal purposes of punishment: D.M. Kahan, "Punishment Incommensurability" (1998) 1 Buff. Crim. L. Rev. 691. This latter theory seems inappropriately harsh in the youth justice context and inconsistent with the emphasis placed in the YCJA on reconciliation and reintegration.

In a typical family conference both the offender and the victims give their side of what happened. The victim's story is often crucial in making the offender see the psychological, economic and social consequences of the offence.

"Conditions of Successful Reintegration Ceremonies: Dealing with Juvenile Offenders" (1994) 34

Br. J. of Criminology 139 at $147-49$.

G. Maxwell \& A. Morris, "Research on Family Group Conferences with Young Offenders in New Zealand" in J. Hudson \& B. Galaway et al.. eds.. Family Group Conferences: Perspectives on Policy and Practice (Annandale: Federation Press. 1996) at 90, 100. See also A. Morris \& G. Maxwell, eds., Restorative Justice for Juveniles: Conferencing. Mediation and Circles (Oxford: Hart Publishing, 2001).

39 J. Braithwaite, "Restorative Justice: Assessing Optimistic and Pessimistic Accounts" in M. Tonry, ed., Crime and Justice: A Review of Research (Chicago: University of Chicago Press, 1999) at 2026. 
Victims can be dissatisfied if treated with disrespect, if offered fake apologies and if promises of reparation are broken. Nevertheless, the research so far establishes considerable victim satisfaction with family conferences. Federal spending power should be used to encourage provinces to conduct family conferences in which victims have the opportunity to participate. Family conferences cannot be conducted without adequate resources to conduct the conferences and to prepare the participants beforehand. In New Zealand, in 1993-1994, there were 7,500 family conferences and 50 full-time youth justice co-ordinators. ${ }^{40}$

\section{The Importance of Federal SPEnding Power}

The actual use of various diversion programs (including family conferences) under the $Y C J A$ in many provinces may depend on whether and how the federal government uses its spending power to affect the local administration of justice. Section 156 of the $Y C J A$ is a permissive provision that allows any minister of the Crown to enter into costsharing agreements with a province to deliver any service under the YCJA. It is a recognition of the federal government's spending power and its ability to affect the development of youth justice policy. Although the federal government has committed $\$ 400$ million to implement the new regime, concern is expressed about the adequacy of this sum and the reluctance to return to equal sharing of the costs of diversion programs. ${ }^{41}$ Any federal unwillingness to fund such measures is unfortunate from the perspective of encouraging victim involvement. Section 157 of the YCJA recognizes that the provinces (and the Attorney General of Canada, presumably only in the territories), can establish "victim-offender reconciliation programs, mediation programs and restitution programs" as alternatives to judicial proceedings. However, such programs cannot be administered properly on the cheap, because arranging safe and productive meetings between victims and offenders and ensuring that offenders keep the promises made to victims at such meetings requires extensive effort. Such programs are often staffed by volunteers from the community, but funding is still necessary to ensure proper administration, training and continuity. Federal spending power is crucial to the development of diversion programs. Offenders, and presumably victims, do not have Charter rights requiring that such programs are offered. ${ }^{42}$ Provinces, especially the poorer ones, may hesitate to devise diversion programs that involve victims, unless they are encouraged to do so through federal spending power. It will often be more economical for the provinces to offer diversion programs that do not include crime victims.

\section{Judicial MeASUReS}

The focus in this section is on examining the sentencing-related provisions of the $Y C J A$. First, some provisions relating to the role of victims in the trial process are briefly examined. 


\section{A. Victims and the Trial Process}

The general principles in ss. 3(d)(ii) and (iii) can apply to the trial process and suggest that victims should be treated with courtesy, compassion and respect, that they should suffer the minimum degree of inconvenience, and that they should be informed about the proceedings. As discussed above, these principles are not terribly controversial, but may raise false expectations for victims who may be compelled to testify and subject to cross-examination.

Victims can be excluded from a hearing under s. 132 where there is concern about harm to the young accused, a child is a witness or where the judge determines that closed proceedings are necessary "in the interest of public morals, the maintenance of order or the proper administration of justice." The exclusion of victims from hearings could possibly be justified as a restriction tailored to concerns particular to youth justice, most notably concerns about the rehabilitation of the young person dealt with in the proceedings. At the same time, the potential for victims to be excluded from hearings is in tension with the principle in s. 3(d)(iii) that victims should be provided with information about proceedings and given an opportunity to participate and be heard. However, judges retain the discretion to tailor the exclusion order so that it does not apply to the victim. In most cases, judges would probably allow victims to attend all aspects of the proceedings.

\section{B. Victims and Publication bans}

There are some protections for victims in the trial process. Section 111 provides that, subject to the section, no person shall publish the name or other identifying information of a young victim or witness. In relatively rare cases, victims may not want to be protected by such publication bans. The YCJA is less absolute than the YOA in restricting the publication of the names of young witnesses and victims. ${ }^{43}$ The young victim has a right under s. $111(2)$ to reveal his or her own identity after turning 18 years of age. If under that age, s. 111(2) requires that the consent of his or her parents be obtained. The latter requirement raises the troubling prospect that a parent (who may even be the perpetrator of the offence) has a veto over a young person who, for whatever reason, wants to publicize that he or she was a victim of a crime. Even where parents are not involved in the crime, they may have an interest in keeping their child's involvement as a victim of a crime quiet, even though that young person (someone as old as 17 years) wants to publicize his or her involvement. Less troublesome is the parents' power to decide whether to publicize their child's name as a victim where the child is deceased.

Section 111(3) allows a young victim to apply to the court for an exemption from the ban. The Court can grant such an exemption if satisfied that it "would not be 
contrary to his or her best interests or the public interest." This may provide a means for young people to circumvent their parents' refusal to allow their name to be publicized. The Court is effectively placed in the paternalistic position of deciding whether publication would be in the young person's best interests. Even if publication is not in the young person's best interests, it may be authorized by the Court if found to be in the public interest.

\section{A New Emphasis on Reparation in SENTENCing}

The sentencing provisions of the $Y C J A$ stress proportionality and accountability, while also incorporating some victim concerns. Section 38(2)(e)(iii) tracks s. 718(f) of the Criminal Code by providing that, subject to the principle of proportionality, sentences should "promote a sense of responsibility in the young person, and an acknowledgement of the harm done to victims and the community." Section 38(3)(c) resembles s. 718(e) of the Criminal Code in its provision that "any reparation made by the young person to the victim or the community" should be taken into account in determining the sentence. In following the Criminal Code, it is clear that the above sections of the $Y C J A$ are not particular to youth justice, but apply to the sentencing of all offenders. At the same time, there is a persuasive argument that recognizing harm and providing reparation are particularly important to youth justice because they encourage young offenders to face and accept the consequences of their actions consequences that they as young people might not readily appreciate.

As discussed above, there is ambiguity in acknowledging harms and making reparation to the community on the one hand, and to victims on the other. Reparation and acknowledgement of harm to the community may not be fundamentally different from the traditional punitive purposes of punishment. Victims benefit indirectly - at best - when an offender goes to prison or pays a fine to acknowledge and repair harm done to the community. On the other hand, the acknowledgement of harm and reparation to victims, as opposed to the community, introduces genuinely new concerns into youth justice. Acknowledgement and reparation to the victim provide a direct benefit to the victim by responding to his or her needs. As the Supreme Court of Canada recognized, such restorative sanctions generally do not involve the use of imprisonment (which may actually make it more difficult for the offender to make reparation to the victim) ${ }^{44}$ To a young person, the threat of imprisonment may also stand as a barrier to accepting responsibility and acknowledging the harm caused by an offence. If these new purposes of sentencing are genuinely to change youth justice, judges must be encouraged to stress the restorative principle of acknowledging and repairing harm to victims over the potentially punitive notion that the offender should acknowledge and repair harm to the community.

\section{REPARATION: MORE THAN MONEY?}

Section 38(3)(c) requires trial judges to take into account "any reparation made by the young person to the victim or the community." Encouraging young offenders to 
repair the damage caused by their crime can be defended as particularly appropriate in youth proceedings. Because of their youth, young offenders may not realize the cost of their crimes. Nevertheless, it is important that the cost of crime not be exclusively conceived of in monetary terms: it should include genuine apologies and attempts to make amends. It would be out of harmony with the rest of the $Y C J A$ to limit reparation purely to the transfer of money. For example, in imposing a maximum $\$ 1,000$ fine, judges are instructed under s. 54(1) to "have regard to the present and future means of the young person to pay." It would seem strange if such considerations played no role with respect to reparation. Reparation should be defined in the $Y C J A$ to include not only monetary restitution, but genuine attempts to apologize and recognize the harm of the crime.

Very few young offenders are in a position to make monetary restitution, particularly in cases involving more than trivial harm. In a conditional sentencing case, the Supreme Court of Canada recognized that a $\$ 10,000$ payment by the employer to an employee that he assaulted and sexually assaulted achieved the restorative principles of sentencing contemplated under the Criminal Code. ${ }^{45}$ The possible value of such a payment in reducing an offender's sentence raises real distributional concerns. How many young offenders will have savings or access to family savings to make such payments? If the new emphasis on reparation in the $Y C J A$ is conceived of narrowly as monetary reparation, and if policy-makers do not make possible forms of reparation other than direct cash payments, there is a real danger that only those victims harmed by advantaged offenders will receive reparation, and that disadvantaged offenders may be penalized for their inability to make financial reparation to their victims.

\section{E. ReParation and the Circumstances of ABoriginal OfFenders}

The new emphasis on reparation in the $Y C J A$ should not disadvantage Aboriginal and other economically-disadvantaged youths who do not have the funds for financial reparation, even for minor property offences. Special attention to the circumstances of Aboriginal offenders is mandated by the last-minute amendments to the $Y C J A$ initiated by the Senate. As a result of these amendments, s. 38(2)(d) of the YCJA tracks s. 718.2(e) of the Criminal Code in recognizing Aboriginal overrepresentation in custody by prescribing that "all available sanctions other than custody that are reasonable in the circumstances should be considered for all young persons, with particular attention to the circumstances of aboriginal young persons." 46

One Canadian study of an Aboriginal-specific victim-offender reconciliation program found no actual reparation, in part because none of the offenders had jobs. ${ }^{47}$ Only 2 percent of cases referred to Aboriginal Legal Service of Toronto's Community Council

is $\quad$ R. v. R.(R.A.), [2001] I S.C.R. 163.

th The leading case interpreting this section is Gladue, supra note 6. On that case and s. 718.2(e) see K. Roach \& J. Rudin, "Gladue: The Judicial and Political Reception of a Promising Decision" (2000) 42 Can. J. Crim. 355; J. Rudin \& K. Roach, "Broken Promises: A Response to Stenning and Roberts' 'Empty Promises"” (2002) 65 Sask. L. Rev. 3.

47 L. Longclaws et al., "Piloting Family Group Conferences for Young Offenders in Winnipeg" in Hudson \& Galaway et al., supra note 38 at 193. 
resulted in monetary restitution. ${ }^{48}$ Thus, it is consistent with the intent of $s .38(2)(d)$ in responding to the overrepresentation of Aboriginal youth in custody to not restrict reparation to monetary restitution because many Aboriginal youths, and other disadvantaged offenders, will not have access to funds. Although s. 38(2)(d) singles out Aboriginal offenders for particular attention, it also addresses the need to reduce reliance on incarceration for all offenders, and it would be consistent with the spirit of s. 38(2)(d) and other sections of the $Y C J A^{49}$ not to restrict reparation to monetary restitution.

\section{F. Reparative Sentences}

Judges will have to be creative in devising sentences if they are to give adequate weight to the new emphasis placed on reparation in the $Y C J A$ and to ensure that reparation is not reduced to monetary restitution in a manner disadvantageous to Aboriginal, and other economically-disadvantaged, offenders. Fortunately, there are several provisions in the $Y C J A$ that encourage judges to craft sentences for young offenders that facilitate broad forms of reparation to victims. Section 40(2)(d)(i) encourages pre-sentence reports that address the young person's "willingness to make amends." This should be interpreted broadly to include more than the ability of young offenders to draw on their savings, or the savings of their family, to make reparation. Sections 42(2)(e), (f) and (g) advance a narrower view of reparation as monetary restitution by contemplating restitution orders for readily-ascertainable pecuniary losses. These provisions raise the issue of whether young offenders will have the ability to repay such damages. Even if they could pay reparation, there is the further question of whether victims will be satisfied with pecuniary, as opposed to non-pecuniary, damages. Money to repair a broken window or door may not respond to the insecurity that one feels after a break-in. In some cases, it may be in the interest of both offenders and victims to conceive of reparation and amends as involving more than purely the transfer of funds.

Other forms of reparation may be ordered as a condition of probation. Section 55 does not specifically list reparation as one of the conditions, but s. 55(2)(h) permits a youth court judge to order that the young person "comply with any other conditions set out in the order that the youth justice court considers appropriate, including conditions for securing the young person's good conduct and for preventing the young person from repeating the offence or committing other offences." This basket clause may permit community service orders that provide reparation to the victim.

Section 42(2)(h) is more innovative because it allows the sentencing judge to "order the young person to compensate any person in kind or by way of personal services" for

Due Process, supra note 11 at 276.

Section 3(c)(iv) of the YCJA provides that measures taken against young people should "respect gender, ethnic, cultural and linguistic differences and respond to the needs of aboriginal young persons and of young persons with special requirements." Some have criticized s. 718.2(e) of the Criminal Code as under-inclusive in singling out Aboriginal people as disadvantaged offenders. P. Stenning \& J.V. Roberts, "Empty Promises: Parliament, The Supreme Court, and the Sentencing of Aboriginal Offenders" (2001) 64 Sask. L. Rev. 137. 
pecuniary damages. The order cannot exceed 240 hours of community services or 12 months. ${ }^{50}$ The judge making such an order must also be satisfied that the young person is a suitable candidate and that the order does not interfere with the young person's normal hours of work or education. ${ }^{51}$ The victim compensated must also consent to the personal service order. ${ }^{52}$ This is appropriate because a s. 42(2)(h) order will involve continued contact between the offender and the victim, and the victim's wishes in this regard should be respected. Section $42(2)(h)$ is an innovative provision that points in the right direction in ensuring that the new emphasis on reparation is not limited to monetary restitution. However, this provision is not sufficient. In many cases, crime victims may feel uncomfortable with continued contact with the offender and may not consent to such an order.

To make the restitution option meaningful for the most disadvantaged offenders may require the establishment of programs analogous to fine option programs that provide youths with the opportunity to work and earn money to make reparation to victims. ${ }^{53}$ Perhaps a program like the innovative s. $42(2)(\mathrm{h})$ order - but writ large, and not dependent on the young person having to provide personal services to the crime victim with his or her consent. Such a program might also resemble community service orders made under s. 42(2)(i), except that the victim would benefit from the offender's work, as opposed to the community at large. Such programs would be established by the provinces but federal spending power could be used to support them. A failure to devise such programs may mean that the new emphasis on reparation in the YCJA may provide a false promise for victims not fortunate enough to have offenders who come from advantaged backgrounds that can draw on family savings to make reparation. It will also mean that young offenders from disadvantaged backgrounds will be further disadvantaged by not being able to satisfy the reparative purposes of sentences. This could, contrary to the intent of s. 38(2)(d), aggravate the over-incarceration of Aboriginal youth and other disadvantaged individuals.

\section{G. Fines AND Fine SURChARgeS}

Young offenders can be fined up to $\$ 1,000$ under the $Y C J A,{ }^{54}$ and the provinces may establish a victim fine surcharge of any percentage of that fine, with the funds being used "to provide such assistance to victims of offences as the lieutenant governor in council may direct from time to time." victim fine surcharge, the youth court judge has the discretion to impose a victim fine surcharge not exceeding 15 percent of the fine. ${ }^{56}$ Young offenders can pay off both the fine and the victim surcharge through fine option programs, but only where such

\footnotetext{
so YCJA, supra note 1, s. $54(8)$.

s1 Ibid., s. 54(7).

52 Ibid., s. 54(6).

s. K. Roach, "Crime Victims and Sentencing" in D. Stuart, R.J. Delisle \& A. Manson, eds., Towards a Clear and Just Criminal Law: A Criminal Reports Forum (Toronto: Carswell, 1999) at 513-19.

st $Y C J A$, supra note 1 , s. $42(2)(\mathrm{d})$.

ss $\quad$ lbid., s. 53(1).

36 Ibid., s. 53(2).
} 
programs are available. ${ }^{57}$ Victim fine surcharges may provide a modest amount of money for victim services, but such surcharges will serve no direct restorative purpose. They will likely, and not unreasonably, be perceived by the young offender as a tax on the fine. ${ }^{58}$

\section{H. SUMMARY ON REPARATION}

There is the danger that the new emphasis on reparation in the $Y C J A$ may be an example of a neo-liberal privatization of core state functions, in this case the function of imposing punishment. The focus on reparation may allow young offenders that come from advantaged families to pay down their punishment by giving part of their savings, or their family's savings, to the crime victim. Although the crime victim may be a deserving party, such payments are unfair if they allow governments to cut back on the compensation that is available to all crime victims (and arguably victims of other misfortunes). Such payments are perhaps most unfair to young offenders who come from disadvantaged backgrounds. These offenders, including the vast majority of young Aboriginal offenders, will not be able to have their sentence reduced by making monetary restitution to their victims. Thus, it is important that governments take steps in implementing the $Y C J A$ to ensure that all offenders and all victims have an equal opportunity to benefit from the $Y C J A$ 's new emphasis on reparation. Federal spending power can play an important role in making fine option programs viable, and hopefully expanding them to allow young people to work in order to make reparation to victims. If programs are available allowing young people to earn money to pay off the fines they owe the state, it seems only fair that similar programs should allow young people to pay off the debts owed to victims.

\section{VICTIM IMPACT STATEMENTS}

Section $40(2)(b)$ provides that the results of an interview with the victim of the offence may be included, where "applicable and reasonably possible," in the presentence report. However, the victim does not have a right under s. 40(5) to see the presentence report. Even a private prosecutor may not have access to a pre-sentence report where it is not necessary for the prosecution of the case and would be prejudicial to the young person. ${ }^{59}$ Lack of disclosure of pre-sentence reports may cause problems if victims believe their concerns are not being fairly represented in the pre-sentence report.

Section 50 of the $Y C J A$ provides that $\mathbf{s} .722$ of the Criminal Code governing victim impact statements applies to proceedings in youth court. Thus, in a very real sense, the right to make victim impact statements has been extended from adult to youth justice proceedings in a generic fashion without any tailoring to the particular concerns of youth justice. This is not a new provision, but simply follows s. $20(8)$, which was

Ibid., s. 54(2).

s\$ For early scepticism about the victim fine surcharge see B. Dickson, "The Forgotten Party - the Victim of Crime" (1984) 18 U.B.C. L. Rev. 319. 
added to the $Y O A$ in $1995 .^{60}$ What is new are the recent amendments to s. 722 of the Criminal Code giving victims the right to read their statements in court or present them in any other manner (videotape, for example) that the Court considers appropriate. The matter is not without controversy, but the better view seems to be that this amendment should allow victims to read their victim statements in court. ${ }^{61}$

Section 50 of the YCJA also makes s. 722.2 of the Criminal Code applicable to youth proceedings. $^{62}$ Consequently, youth court judges are required "as soon as practicable after a finding of guilt and in any event before imposing sentence" to inquire of the prosecutor or the victim whether the victim has been advised of the opportunity to prepare a victim impact statement, and may adjourn proceedings to allow such a statement to be obtained. Section 722.2 was designed to respond to the low percentage of cases in which victim impact statements were used. ${ }^{63}$

It remains to be seen whether the new obligations under s. 722.2 will increase the use of victim impact statements in youth court, and whether this will have any effect on sentences. The available research suggests that victim impact statements typically do not have a noticeable effect on sentencing. ${ }^{64}$ The question also remains whether victims will benefit from victim impact statements. More research needs to be done, but there is some cause for scepticism. Victims may be subject to adversarial crossexamination on their statement. Some forms warn victims of this possibility and candidly inform victims that it is for the trial judge to decide what weight, if any, will be accorded the victim impact statement. Victim impact statements encourage victims to focus on the harm that the crime has caused. Although victim impact statements should not make recommendations as to sentence, ${ }^{65}$ their use may encourage crime victims to tie their hopes to punishment. However, the available research suggests that victim impact statements will not result in noticeable increases in sentences. I conclude elsewhere that "victim impact statements remain a symbolic and punitive reform. Even in the infrequent cases in which they were introduced, the traditional reluctance of judges to base the sentencing on victims' suffering may not have changed. Crime

Anand, supra note 24 at 254.

(1) The intent of the provision seems to be to allow victims to read their impact statements in court, and many forms for preparing such statements indicate that the victims can make such oral presentations. J. Roberts, "Victim Impact Statements and the Sentencing Process: Recent Developments and Research Findings" (2003) 47 Crim. L.Q. [forthcoming]. Alan Manson, however, argues that judges can prevent a victim from reading the victim impact statement, as long as the judge allows the statement to be presented in some other manner: The Law of Sentencing (Toronto: Irwin Law, 2001) at 197-98.

An earlier version of the bill did not make s. 722.2 applicable to youth proceedings. See Bill C-3, An Act in respect of criminal justice for young persons and to amend and repeal other Acts, $2 \mathrm{~d}$ Sess., 36th Parl., s. 49(1). This omission was strange given the emphasis that has been placed on victim impact statements, but could perhaps be justified if it is accepted that youth justice should focus less on victim concerns and more on the rehabilitation and reintegration of young offenders. A British Columbia study indicates that victim impact statements were obtained in only 2 to 6 percent of cases and filed in court in only 1 to 2 percent of cases. T. Roberts, Assessment of the Victim Impact Statement Program in British Columbia (Ottawa: Department of Justice, Canada, Research and Development Directorate, Corporate Policy and Programs Sector, 1992).

is $\quad$ R. v. Gabriel (1999), 26 C.R. (5th) 364 (Ont. S.C.) 
victims may be directed to put their hopes in punishment only to be disappointed." 66 Important questions that need to be explored are whether being able to express the harm done by youth crime will increase victim satisfaction, and whether it will have a beneficial effect on offenders by making them realize the harm they have caused.

\section{CONCLusions}

Unlike the $Y O A$, victim concerns are specifically recognized throughout the $Y C J A$. The principles recognize the new emphasis in the Criminal Code and elsewhere on the right of victims to be treated with respect, to be provided with information and to participate in criminal proceedings (mainly through the submission of victim impact statements). In addition, the YCJA reflects the increasing emphasis in the Criminal Code on reparation to victims and the community as a purpose of sentencing.

The role of victims under the $Y C J A$ is difficult to assess with respect to extrajudicial measures. Section 5(b) recognizes that extrajudicial measures should encourage young offenders to acknowledge and repair the harm caused to the victim and the community. This encourages the use of victim-offender reconciliation and restitution programs, contemplated as community-based programs under s. 157 of the $Y C J A$. Given their success in New Zealand in both reducing youth imprisonment and producing significant levels of victim satisfaction, it is surprising and disappointing that family conferences are not specifically encouraged in the $Y C J A$. Family conferences are a non-punitive form of intervention that allow victims to participate, albeit at the risk of causing victims more than minimal inconvenience. They are also well-suited to encouraging young offenders to accept responsibility for their offences and to make attempts at reparation. Family conferences are by no means precluded by the $Y C J A$ : nothing prevents a particular province from introducing them as extrajudicial sanctions under s. 10 or promulgating rules under s. 19(3) that govern when family conferences should be convened and how they should be conducted. Nevertheless, family conferences are not specifically encouraged or structured in the YCJA. Their use will depend on local and provincial practice. The federal government should make robust use of its spending power to encourage the use and evaluation of family conferences and other extrajudicial measures that involve victims, such as victim-offender reconciliation and mediation programs. Such programs may save money in the long run, but they cannot be administered cheaply and victims will have to be given information, support and the free choice to participate. Evaluations designed to measure the level of victim satisfaction should be undertaken.

Victims also have a significant role to play in the implementation of judicial measures. The reparative purposes of punishment are recognized in $\mathrm{s.} 38$ and judges can order a wide range of sanctions to pursue these purposes. However, there is the danger that many young people will not be in the financial position to provide reparation in the form of monetary restitution. There is a need for work programs akin to the innovative orders contemplated under s. 42(2)(h) that provide young offenders with the opportunity to work in order to make reparation. Reparation should be interpreted 
broadly to include genuine attempts by young offenders to recognize and make good the harms they have caused. Reparation creatively devised and implemented recognizes the role of victims in youth justice without relying on imprisonment. There is a persuasive argument that reparation is a particularly appropriate and effective response to youth crime. Young people should be given the opportunity to recognize the real costs of their crime, but they must also be given an equal opportunity to pay those costs. A simple focus on the ability to make monetary restitution from existing family and youth savings will impose further disadvantages on Aboriginal and other disadvantaged youths.

Other parts of the $Y C J A$ lean towards a punitive model of victims' rights. Following the 1995 amendments of the $Y O A$, the $Y C J A$ allows yictim impact statements to be introduced in youth court. Moreover, the $Y C J A$ imposes new requirements on youth court judges to inquire of prosecutors and victims before sentencing if a victim impact statement has been prepared, and to adjourn proceedings to allow such statements to be provided. This may increase the frequency of victim impact statements being introduced in youth court. However, not enough is known about whether this will occur and what effect, if any, such statements will have on sentences and on either young offenders or their victims. Victims may well play an increased role under the $Y C J A$, but the actual effect of both non-punitive and punitive forms of victim involvement in the youth justice system will depend on how the new law is administered. 